\title{
The Influence of Pesticide Carbocide on Soil Microorganisms
}

\author{
Ayna M. Dokhtukayeva \\ Department of cellular biology, morphology and \\ microbiology \\ Chechen state university, Grozny, Russia \\ kurumova71@mail.ru \\ Yakhita S. Usaeva \\ Department of cellular biology, morphology and \\ microbiology \\ Chechen state university, Grozny, Russia \\ y.usaeva@mail.ru \\ Luiza G. Molochaeva \\ Department of cellular biology, morphology and \\ microbiology \\ Chechen state university, Grozny, Russia \\ L_molochaeva@mail.ru
}

\author{
Tanzila M. Khamzatova \\ Department of cellular biology, morphology and \\ microbiology \\ Chechen state university, Grozny, Russia \\ Ibluev89@mail.ru
}

Fatima S. Turlova

Department of cellular biology, morphology and microbiology

Chechen state university, Grozny, Russia turlova.fatima@yandex.ru

Madina M. Arsanova

Department of cellular biology, morphology and microbiology

Chechen state university, Grozny, Russia madina-arsanova@mail.ru

\author{
Amina L. Elderkhanova \\ Department of cellular biology, morphology and microbiology \\ Chechen state university, Grozny, Russia \\ Elderhanova87@mail.ru
}

\begin{abstract}
Pesticides enter the nature as a result of human economic activity and represent a major hazard for people's health. As a result of studying production and experimental cartocide pesticide doses on soil microorganisms we have revealed the biodegradation capability of cartocide. In particular, it has been established that fungicide cartocide is exposed to microbic decomposition by bacteria species of Bacillus and Pseudomonas.
\end{abstract}

Keywords - pesticide, cartocide bacteria, soil microorganisms, decomposition, agent.

\section{INTRODUCTION}

One of negative issues of the present time is global chemical pollution of the biosphere that generates reasonable concern on possible ecological disruption in separate ecosystems $[1,2,7]$. The special danger is constituted by the synthetic nonnatural substances coming to the nature as a result of economic activity of a human [3]. The important place among them is occupied by the chemical crop and animal protection agents - pesticides, one of which is fungicide cartocide. Cartocide is the agent intended to protect from fungal diseases of vegetables, fruit and berry crops, and vineyards. It is recommended to protect vegetables from storage decay. The active fraction of agent is cuprum(II) tricaptolactan, bichloride, monohydrate. The generalized formula of the substance is $\mathrm{C} 18 \mathrm{H} 35 \mathrm{CI} 2 \mathrm{CuN} 3 \mathrm{O} 4$. The molecular weight is 492,0 . It is a green crystal substance with the melting temperature of $80-82{ }^{\circ} \mathrm{C}$. It is very soluble in water, a xylene, chloroform, acetone and ethyl hydroxide. The maximum allowable concentration (MAC) in the air of the working area is $2 \mathrm{mg} / \mathrm{m}^{3}$. Working concentration of $1 \mathrm{mg}$ of r.a. on $1 \mathrm{~kg}$ of soil. It is allowed for protection from mal secco, anthracnose, scab and gray mold (consumption rate of 9-12 kg of r.a./ ha), to decrease losses at storage (including from gray rot) of sugar beet $(10 \mathrm{~g} / \mathrm{t}$ of agents [8].

\section{METHODS AND MATERIALS}

In experiments there were used:

1) Samples of the black soil from fields of the farm enterprise "Bolatbi" in Kurchaloyevskyi district of the Chechen republic.

2) Fungicide cartocide - chlorine-containing heterocyclic hydrocarbon. 
3) The cultures of microorganisms separated from the soil with pesticide: 7 strains of actinomycetes; 9 strains of geterotrophic bacteria; 5 strains of mold fungus [5].

Strains of bacteria from the laboratory of the department of Cellular biology, morphology and microbiology of the Chechen state university: Agrobacterium tumefaciens 8628, Arthrobactersp, Azotobacter beijerinckii, A. chroococcum 800, Bacillus cereus, $B$. mesentericus, $B$. sabtilis, $B$, megateriurn, B. Mycoldes, Clavibacter michigancmis, Erwinia carotovora var citrullis, Pseudomonas syringae, $P$. aeruginosa, P. putida.

There was used the scheme of methods in the study: soil sampling, preparation of the soil and pesticide to the research; entering the pesticide into the soil; sampling of soils and preparation of them to the research; defining dynamics of microorganisms population in the soil with pesticide (experiment) and without pesticide (control); studying the influence of pesticide on the "respiration" intensity of the soil, nitrogenic activity and nitrogen fixation; allocation of microorganisms strains from soil, containing pesticide for long period (30 days); determining sensitivity of pure growths to pesticide; selecting strains growing in the area with pesticide; studying of destructive activity of microbes.

Growing mediums for allocation and cultivation of microorganisms: MIA - meat infusion agar; SAA - starch-andammonia agar; WA - wort agar; Sabouraud environment; M9 - mineral carbon-free environment.

\section{RESULTS}

We have studied the influence of the working $(1 \mathrm{mg} / \mathrm{kg})$ and experimental doses of cartocide $(10 \mathrm{mg} / \mathrm{kg}$ and 100 $\mathrm{mg} / \mathrm{kg}$ ) on changes of quantitative indices of microorganisms in the soil $[4,10]$.

The obtained results demonstrate that all doses of cartocide in the first days of the experiment stimulated geterotrophic bacteria, increasing their quantity by 1.5-2.5 times, in comparison with control (Fig. 1). Moreover, the stimulating effect was intensified by increasing the concentration of the agent. It means that the agent is undergone the degradation by soil microorganisms [6]. However, on the 30th day we revealed that the quantitative indices of bacteria had been decreased to control level. Perhaps, the cartocide was quickly available substratum for them, and it was abundantly used as nutritious and energy material. At the same time actinomycetes practically did not take up the agent. Only when a small dose of pesticide was introduced, the number of actinomycetes remained at the initial level. When introducing increased doses the inhibition of growing processes was observed, but on the 30th day their number was restored to control indices (Fig. 2).

Mold fungi were very sensitive to pesticide. We observed the suppression of their growth which lowered their quantitative indices to $70 \%$ (Fig. 3).

By 30 days in the experiment samplings containing working concentration of agent and containing 10 doses, there was weak renewal of mold fungus growth. However, the number of them nevertheless had not reached the control level yet.



Fig. 1. The influence of different cartocide doses on the microorganisms population

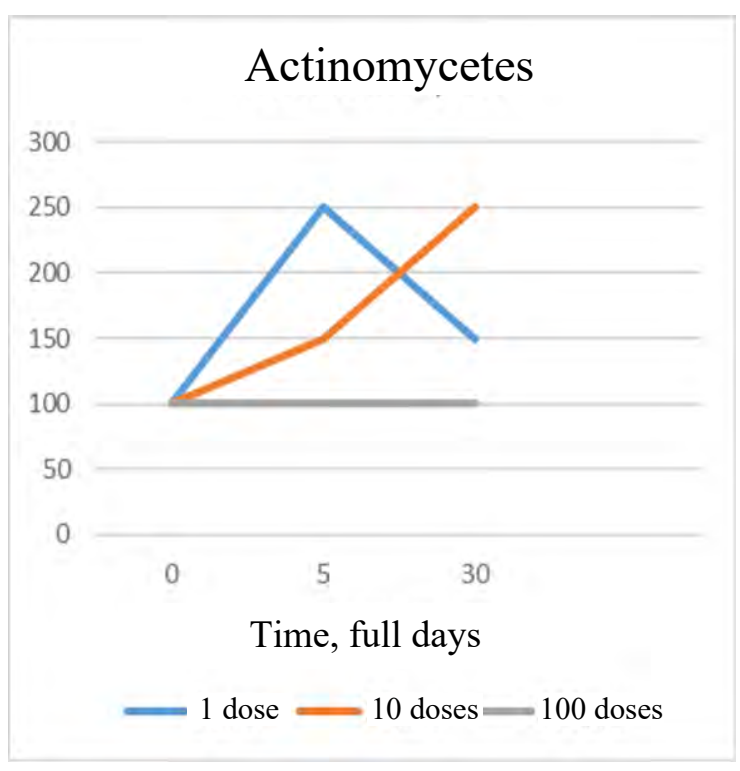

Fig. 2. The influence of different cartocide doses on the microorganisms population. 


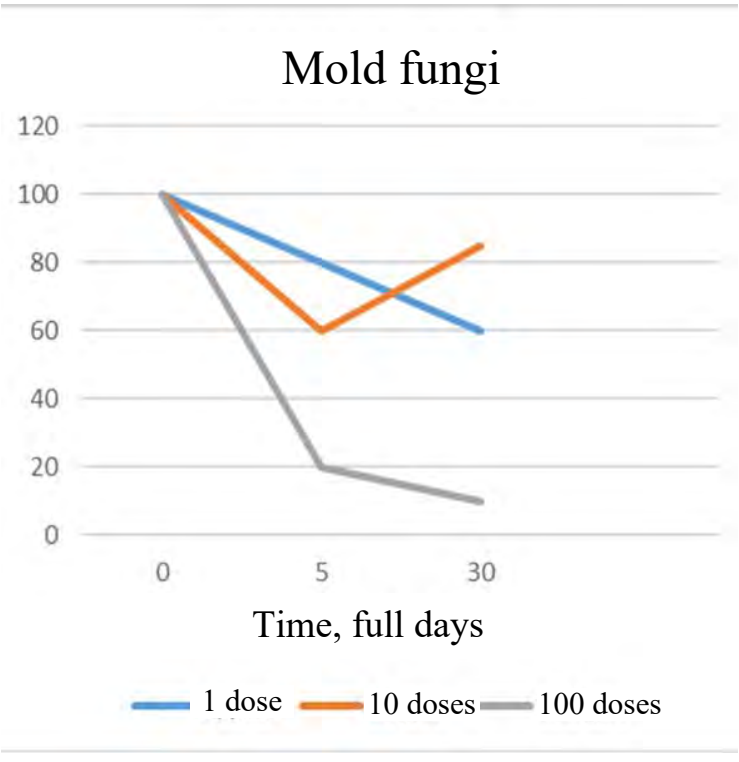

Fig. 3. The influence of different cartocide doses on the microorganisms population.

We isolated 9 strains of geterotrophic bacteria from the soil containing pesticide to test them for sensitivity to the agent. The data presented in the table 1 demonstrate that 3 species experienced the growth inhibition, the environment with pesticide made the stimulating impact on 5 strains, but 3 strains did not react to the presence of pesticide at the environment (CT equaled to zero). The most sensitive bacteria were yeastlike microbes, coccus forms of bacteria and some strains of Bacillus bacteria. Only gram-negative rodband bacteria grew actively in this environment[10].

These data allow to claim that cartocide suppresses grampositive and stimulates the growth of gram-negative bacteria, that proves the selective effect of the agent. Perhaps, it breaks the synthesis of a cell wall by the b-lactam antibiotics type.

Due to the use of a cartocide is directed to protect from fungal diseases of plants, we were interested in studying its effect on the growth of the phytopathogenic bacteria. As the test-objects the museum strains of bacteria of the Erwinia species were chosen. The representatives of this species are activators of plant soft rot, watermelon parasites, and they cause heavy toxicosis in humans when eating affected fruit and berries. Exo- and endo-toxins of Erwinia cause pathological processes in human and animal bodies. According to the obtained data (Tabl.2) all studied strains had growth inhibition in the environment.

As pesticide had the stimulating effect to the number of geterotrophic bacteria, we supposed that this should be the group of microorganisms that has the strains using pesticide as nutritious and energy substrata. In this regard we have studied the ability of bacteria to use cartocide in metabolism processes. For this purpose the strains allocated from the soil with pesticide were planted to the mineral agarized environment M9 with combinations of carbon substratum. As a source of carbon we added pesticide $(P)$ or glucose $(G)$. According to the environment containing glucose $(\mathrm{M} 9+\mathrm{G})$ we studied the ability of bacteria to grow in the synthetic environment M9; but in the environment containing agent (M9+ P) we revealed the strains using pesticide as a substratum. To confirm splitting of substratum we used the bromthimol blue indicator.

TABLE I. SENSITIVITY OF PURE GROWTHS MICROORGANISMS TO CARTOCIDE $(1 \mathrm{MG} / \mathrm{L})$

\begin{tabular}{|c|c|c|c|}
\hline \multirow{2}{*}{ Strain } & \multicolumn{2}{|c|}{ Colony diameter, mm } & $\begin{array}{c}\text { Inhibition coefficient, } \\
\%\end{array}$ \\
\cline { 2 - 5 } & Control & Experiment & \\
\hline 2 Bacillus sp. & $7.5 \pm 0.5$ & $6.5 \pm 0.8$ & 13 \\
\hline 5Bacillus sp. & $57.5 \pm 0.5$ & $46.5+0.5$ & 21 \\
\hline 4 Bacillus sp. & $6.5 \pm 0.7$ & $3.0 \pm 0.6$ & 54 \\
\hline 5 Proteus sp. & $6.5 \pm 0.4$ & $6.5 \pm 0.5$ & 0 \\
\hline 7 Proteus sp. & $12.5 \pm 0.5$ & $12.0 \pm 0.8$ & 0 \\
\hline 4Pseudomonas sp. & $15.5+$ & $20.0 \pm 0.6$ & -29 \\
\hline 6 Pseudomonas sp. & $8.0 \pm 0.5$ & $9.0 \pm 0.5$ & 53 \\
\hline 11Pseudomonas sp. & $14.5+$ & $15.5 \pm 0.8$ & -12 \\
\hline 1 Sporosarcina sp. & $33.0 \pm 0.7$ & $6.5 \pm 0.6$ & -7 \\
\hline 8 Sporosarcina sp. & $17.0 \pm 0.4$ & $16.5 \pm 0.8$ & 80 \\
\hline 9 Staphylococcus sp. & $15.0 \pm 0.6$ & $7.0 \pm 0.5$ & 29 \\
\hline
\end{tabular}

TABLE II.

SENSITIVITY OF ERWINIA STRAINS TO CARTOCIDE (1 $\mathrm{MG} / \mathrm{L}$ )

\begin{tabular}{|l|c|c|c|}
\hline \multirow{2}{*}{ Bacterial species and strain } & \multicolumn{2}{|c|}{$\begin{array}{c}\text { Colony diameter, } \\
\mathbf{m m}\end{array}$} & $\begin{array}{c}\text { Inhibition coefficient, } \\
\%\end{array}$ \\
\cline { 2 - 4 } & Control & Experiment & \\
\hline Envinia amyiavora 75 & $6.4 \pm 0.5$ & $5.3 \pm 0.4$ & 17 \\
\hline $\begin{array}{l}\text { E. carotovora var. citrullis } \\
\text { MИ }\end{array}$ & $11.7 \pm 0.2$ & $1.5 \pm 0.5$ & 87.2 \\
\hline $\begin{array}{l}\text { E. carotovora var. citrullis } \\
\text { 15 }\end{array}$ & $9.6+0.2$ & $1.9 \pm 0.6$ & 80.2 \\
\hline $\begin{array}{l}\text { E. carotovora var. citrullis } \\
438\end{array}$ & $6.4 \pm 0.3$ & $4.5 \pm 0.5$ & 29.6 \\
\hline $\begin{array}{l}\text { E. carotovora var. citrullis } \\
9011\end{array}$ & $5.4 \pm 0.4$ & $2.4 \pm 0.4$ & 55.5 \\
\hline
\end{tabular}

\section{CONCLUSION}

We have studied 9 strains of heterotrophic bacteria, $60 \%$ of which are cultures of Bacillus bacteria, $40 \%$ of gram negative rod-like bacteria and cocci, and 5 strains of mold fungi. The obtained data (Tabl. 1) have allowed to reveal 5 strains of the heterotrophic bacteria using pesticide as the only source of carbon and energy. 


\section{References}

[1.] N.D. Ananyeva, Microbiological aspects of self-cleaning and soil stability. Moscow: Nauka, 2003, p. 223.

[2.] Zh. Voynova-Raykova, V. Raykov, Microorganisms and fertility. Moscow: Prosveshenie, 1986, pp. 91-96.

[3.] G.A. Zavarzin, Lectures on nature study microbiology. Moscow: Nauka, 2003, pp.192-193.

[4.] V.N. Leontyev, I.M. Burak, T.N. Akhramovich., N.V. Grits, "Biodegradation of s-triazine herbicides bacteria species of Pseudomonas". Minsk, BSU, 2000. pp. 41-42. [II. Proceedings of the International conference «Xenobiotics and live systems», 2000].

[5.] Berdzhi's bacteria definer. Moscow: Mir, 1997, p. 800
[6.] E.V. Mitsevich, I. P. Mptsevich, V.V. Perelygin, N.L. To, T.H. Nguyen, "Microorganisms as possible indicators of integrated impurity of dioxined defoliant soils", Applied biochemistry and microbiology, 2000, vol. 36 (6), pp. $672-678$.

[7.] V.S. Shevelukha, E.A. Kalashnikova, E.S. Voronin, Agricultural biotechnology. Moscow: Vysshaya Shkola, 2003, pp. 72-75.

[8.] J. Tekel, T. Hudecona, K. Pecnikova, "Isolation and Pufication Techniques for Pesticides Residue Analisis in Samples of Plant and Animal Origin", European Food Res, and Tech., 2001, pp. 1-16.

[9.] C. Menzie, Metabolism of Pesticides. Washington, 1989, p.387.

[10.] P. Mulchandani, Y. Lei, W. Chen, J. Wang, A. Mulchandani, Microbial biosensor for p-nitrophenol using Moraxella $s p$., Analityca Chimica Acta, 2002, vol.470, pp. 79-86. 